\title{
Differential Antimicrobial Effectiveness of Camel Lactoferrin-Oleic Acid and Bovine Lactoferrin-Oleic Acid Complexes against Several Pathogens
}

\author{
Nawal Abd El-Baky* \\ Protective and Therapeutic Protein Laboratory, Protein Research Department, Genetic Engineering and Biotechnology \\ Research Institute, City for Scientific Research and Technology Applications, New Borg El Arab, Alexandria 21934, Egypt
}

Received: May 14, 2018; Accepted: June 01, 2018; Published: June 12, 2018

*Corresponding author: Nawal Abd El-Baky, Protein Research Department, Genetic Engineering and Biotechnology Research Institute, City for Scientific Research and Technology Applications, Universities and Research Centre District, Ahmed Zewail St, New Borg El Arab, Alexandria 21934, Egypt, Tel.+2034593422, Fax: +2034593407,E-mail: nawalabdelbaky83@gmail.com

\begin{abstract}
Considering the superior biological activities of Camel Lactoferrin (cLf) over lactoferrin from other animal species; which we previously confirmed and continuing the analysis of antimicrobial effectiveness of cLf; we started in previous studies, the current study aimed to formulate a protein-fatty acid complex of cLf and Oleic Acid (OA) and to compare it's in vitro antimicrobial activities against different pathogens with those of a similar Bovine Lactoferrin (bLf)-OA complex. Antimicrobial activity of these complexes was evaluated by agar disc diffusion method, broth microdilution assay, and ELISAestimating $\mathrm{Lf}$ and its complexes binding to bacterial outer membrane proteins. Agar disc diffusion assay results revealed that inhibitory activity of both free cLf and cLf-OA against 13 test pathogens (Methicillin-Resistant Staphylococcus Aureus (MRSA), Staphylococcus aureus, Bacillus cereus, Escherichia coli, Salmonella typhi, Shigella sonnei, Klebsiella pneumonia, Pseudomonas aeruginosa, Proteus vulgaris, Serratia marcescens, Candida albicans, Aspergillus niger, and Aspergillus flavus) noticeably exceeded that of corresponding bLf and bLf-OA. Additionally, free OA exhibited antimicrobial activity against MRSA, S. aureus, B. cereus, and C. albicans and to a lesser extent against E. coli, K. pneumonia as well as A. niger and A. flavus. Consequently, synergy was evident between cLf/bLf and OA (mostly higher in case of cLf) in prepared complexes against MRSA, S. aureus, B. cereus, and C. albicans. cLf-OA demonstrated 4 times lower Minimum Inhibitory Concentration (MIC) values against MRSA, B. cereus, and C. albicans than bLf-OA; indicating more superiority in case of cLf-OA than free cLf that showed only twice the activity of bLf. ELISA signals confirmed binding of biotinylated cLf/bLf and cLf/bLf-OA to bacterial membrane proteins. This study proves that cLf obtains enhanced antimicrobial activities after complex formation with fatty acids such as $\mathrm{OA}$ even than its free form which has already superior activity than other Lf species; thus this complex may be used as a cure of various microbial infections.
\end{abstract}

Keywords: Antimicrobial; bovine lactoferrin; camel lactoferrin; oleic acid; protein-fatty acid complexes

\section{Introduction}

Lactoferrin is an $80 \mathrm{kDa}$ iron-binding glycoprotein, which is found in numerous secretory fluids, for example milk [1]. Lf displays antimicrobial activity against a variety of pathogenic microorganisms besides modulating the immune system. Most published studies aimed to reveal therapeutic utilization of bLf and Human Lactoferrin (hLf) for treatment of various infectious and inflammatory diseases, but fewer studies have been reported on cLf. Evidences point to the differences in the biological (antimicrobial) activities between cLf and other lactoferrins. It was found that cLf was the most active lactoferrin against many pathogens $[2,3]$.

Lactoferrin has a variety of biological functions, many of which not related to its iron-binding capability [4]. Lf is an important part of the innate immune system. Besides its major biological function, which is binding and transport of iron ions, lactoferrin has various other functions such as antibacterial, antifungal, antiparasitic, antiviral, antiallergic, catalytic, and anticancer functions. Lf exhibits diverse inhibitory effects against microorganisms, including stasis, cidal, synergistic, bacterial adhesion blocking, opsonic, and cationic mechanisms. Due to broad-spectrum activities of Lf against various bacteria, fungi, parasites, and viruses, along with its immunomodulatory and anti-inflammatory functions, lactoferrin seems to have great impact on practical medicine [5].

$\mathrm{OA}$; the key monounsaturated fatty acid of olive oil has the ability of in vitro killing of different bacterial and fungal pathogens. Long-chain unsaturated fatty acids such as OA and linoleic acid are bactericidal to various pathogens including MRSA and Helicobacter pylori [6,7]. Also, they have in vitro killing activity against $C$. albicans [8].

Both LF and $\alpha$-Lactalbumin ( $\alpha$-LA) have similar iron-binding region structure [9]. It was confirmed that these proteins release the bound ions at acid $\mathrm{pH}$ to produce a more open structure; a property that favors OA binding [10-12]. 
Therefore, in this study, complexes of cLf and bLf with OA were obtained. Then for the first time, their differential antimicrobial activity against several pathogens was evaluated by agar disc diffusion method and broth micro dilution assay, meanwhile, estimating Lf binding to bacterial outer membrane proteins by ELISA.

\section{Materials and Methods}

\section{Antimicrobial Agents}

cLF and bLf were purified from camel and bovine milk after processing at our lab according to the protocol described by Redwan \& Tabll (2007) [13]. Both purified cLf and bLf preparations were sterilized by filtration through $0.22 \mu \mathrm{m}$ syringe filter (TPP, St. Louis, Mo., USA) and stored at $-20^{\circ} \mathrm{C}$ until use. The iron saturation of both lactoferrins, checked by spectrophotometry, was of approximately $10 \%$ in case of bLf and $35 \%$ in case of cLf (partially iron-saturated) [14]. The protein content was tested by the Folin phenol reagent [15]. OA (C18:1:9 cis, $\geq 99.0 \%$ purity, cell culture tested) was purchased from Sigma-Aldrich (St. Louis, MO, USA).

Discs of 5 antibacterial agents, including carbenicillin $(10 \mu \mathrm{g})$, vancomycin $(30 \mu \mathrm{g})$, fucidic acid $(10 \mu \mathrm{g})$, gentamicin $(10 \mu \mathrm{g})$, and chloramphenicol $(30 \mu \mathrm{g})$ were purchased from Mast Diagnostics (Merseyside, UK). Nystatin and amphotericin-B antifungal standards at concentration of $100 \mu \mathrm{g} / \mathrm{ml}$ were obtained from Sigma-Aldrich.

\section{Determination of cLf and bLf Activity}

Activity of both lactoferrins was assayed according to the procedure described by Ye et al. with slight modifications [16]. Samples of lactoferrin $(50 \mu \mathrm{l})$ were added to the mixture containing $15 \mu \mathrm{l}$ of $50 \mu \mathrm{M}$ Tris-HCl buffer (pH 8.0), and $75 \mu \mathrm{l}$ of $300 \mu \mathrm{M}$ dihydro-nicotinamide-adenine-dinucleotide-phosphate, $300 \mu \mathrm{M}$ Nitroblue Tetrazolium (NBT), and $30 \mu \mathrm{M}$ of Phenazin Methosulfate (PMS). The absorbance was checked at 0 and 5 min of reaction at $580 \mathrm{~nm}$. L-ascorbic acid was used as a control. The calculations were based on standard curve prepared with different concentrations of NBT. LF activity was expressed in IU per milligram of protein.

\section{Preparation of cLf-OA and bLf-OA Complexes}

Both lactoferrins were dissolved in $10 \mathrm{mM}$ phosphate buffered saline (PBS, pH 8.0) to different concentrations. OA was directly added to each protein solution at 50 molar equivalents (OA: Lf). After vortexing for $30 \mathrm{~s}$, the mixtures were incubated for $20 \mathrm{~min}$ at $45^{\circ} \mathrm{C}$ in a water bath. Finally, excess fatty acid in the complexes was removed by centrifugation at $4{ }^{\circ} \mathrm{C}$ followed by ultra filtration using a $3000 \mathrm{kDa}$ cut-off membrane.

\section{Oleic Acid Determination in the Prepared Complexes}

OA concentration in the prepared complexes was determined according to the colorimetric method of Duncombe [17]. In brief, protein complexes were shaken with chloroform and copper solution. Copper amount in chloroform is corresponding to the amount of $\mathrm{OA}$ in the test samples, which is examined by adding sodium diethylthiocarbamate as a color developer. Copper reagent $(2.5 \mathrm{ml})$ consisting of 9 volumes of $1 \mathrm{M}$ triethanolamine, 1 volume of $1 \mathrm{~N}$ acetic acid, and 10 volumes of $10 \%(\mathrm{w} / \mathrm{v})$ copper sulphate was added to either $500 \mu$ l test samples or $500 \mu \mathrm{l}$ standard OA. After shaking vigorously with a vortex mixer, $5 \mathrm{ml}$ chloroform were added to the solution and shaken vigorously for $1 \mathrm{~min}$. Then, $3 \mathrm{ml}$ of the lower layer were carefully transferred to another test tube containing $500 \mu \mathrm{l}$ of $0.1 \%$ sodium diethylthiocarbamate in butanol and absorbance values were recorded at $440 \mathrm{~nm}$. Experiment was done three times, each in triplicate and the results were presented as mean \pm SEM.

\section{Test Microorganisms and Growth Conditions}

MRSA clinical isolate was obtained from blood of a patient at Almery University Hospital (Alexandria, Egypt) and subjected to the confirming BD GeneOhm ${ }^{\mathrm{TM}}$ MRSA assay. The Staphylococcus aureus ATCC 25923 and Candida albicans ATCC 10231 strains were purchased from Becton Dickinson (France). Escherichia coli ATCC 25922, Salmonella typhi ATCC 19430, and Shigella sonnei ATCC 25931 were obtained from American type culture collection (ATCC, USA). Bacillus cereus, Klebsiella pneumonia, Pseudomonas aeruginosa, Proteus vulgaris, Serratia marcescens, Aspergillus niger, and Aspergillus flavus were collected from AlAzhar University Mycology Center (Cairo, Egypt), and Botany and Microbiology Department, Faculty of Science, Al-Azhar University, Assiut Branch (Egypt).

A $100 \mu \mathrm{l}$ aliquot culture of each bacterial strain was added to Luria Bertani (LB) broth, incubated at $37^{\circ} \mathrm{C}$ for $24 \mathrm{~h}$, and then stored at $-80{ }^{\circ} \mathrm{C}$ after addition of $20 \%$ glycerol to be used as seeds stock. Yeasts such as $C$. albicans and fungi such as A. niger and $A$. flavus were maintained on Sabouraud's dextrose agar at $4{ }^{\circ} \mathrm{C}$. To determine in vitro antibacterial activity, Cation-Adjusted MuellerHinton (CAMH) broth and Mueller-Hinton agar were used. While, in vitro antifungal activity was determined using Sabouraud's dextrose broth and Sabouraud's dextrose agar.

\section{Agar Disc Diffusion Assay}

Susceptibility screening of test microorganisms to cLf, bLf, $\mathrm{OA}$, cLf-OA, bLf-OA, and different antibacterial and antifungal standards was carried out using the agar disc diffusion technique on Mueller-Hinton agar for bacteria and Sabouraud's dextrose agar for fungi. Plates were overlaid with $100 \mu$ of standardized inoculum suspension using McFarland standard, then wells were bored into the agar media by using a sterile $6 \mathrm{~mm}$ cork borer, and about $100 \mu \mathrm{l}$ of solutions containing different concentrations of cLf, bLf, OA, cLf-OA, and bLf-OA were added into each well. Carbenicillin, vancomycin, fucidic acid, gentamicin, chloramphenicol, nystatin, or amphotericin-B was used as positive control and sterile water was used as negative control. The culture plates were incubated at $4{ }^{\circ} \mathrm{C}$ for $2 \mathrm{~h}$ to allow proper diffusion of tested antimicrobials before being incubated at $25^{\circ} \mathrm{C}$ and $37{ }^{\circ} \mathrm{C}$ for $24 \mathrm{~h}$ in case of C. albicans and bacterial cultures, respectively, and for 5 days at $25^{\circ} \mathrm{C}$ in case of fungal cultures. Then plates were examined for the presence of the inhibition zones. The zone of inhibition was measured and interpreted using the Clinical and Laboratory Standards Institute (CLSI) zone 
diameter interpretative standards [18].

\section{Broth Micro dilution Susceptibility Assay}

The minimum inhibitory concentrations of cLf, bLf, OA, cLf$\mathrm{OA}$, and bLf-OA against test microorganisms were determined by broth micro dilution method as recommended by CLSI [19]. Each 96-well micro titer plate (Greiner, Frickenhausen, Germany) was inoculated with test microorganisms, and then $100 \mu \mathrm{l}$ of CAMH broth or Sabouraud's dextrose broth containing antimicrobial agents in serial dilution were added. The concentrations of cLf, bLf, cLf-OA, and bLf-OA ranged from $0.0312 \mathrm{mg} / \mathrm{ml}$ to $2 \mathrm{mg} / \mathrm{ml}$, while for $\mathrm{OA}$ were from $1.25 \mathrm{mM}$ to $10 \mathrm{mM}$. Plates inoculated with bacteria and C. albicans were incubated at $37{ }^{\circ} \mathrm{C}$ and 25 ${ }^{\circ} \mathrm{C}$, respectively for $24 \mathrm{~h}$, whereas plates inoculated with fungi were incubated at $25^{\circ} \mathrm{C}$ for 5 days. The MICs were determined by measuring the absorbance at $600 \mathrm{~nm}$ for test bacterial strains and C. albicans and calculating fungal sporulation using hemocytometer. The MIC was defined as the lowest concentration at which growth was completely inhibited. All MIC determinations were performed in duplicate. Bacteria in CAMH broth and fungi in Sabouraud's dextrose broth were used as control of growth.

\section{Detection of Lf and its Complexes Binding to Bacterial Membrane Proteins by ELISA}

Bacterial membrane fractions were prepared from Grampositive and Gram-negative bacteria under investigation. Test bacterial cells were harvested via centrifugation of their cultures and then washed with PBS at pH 7.4. Cells were suspended in $0.5 \mathrm{mg} / \mathrm{ml}$ herbimycin $\mathrm{A}, 0.1 \mathrm{mM}$ sodium vanadate, $25 \mathrm{mg} /$ $\mathrm{ml}$ leupeptin, $50 \mathrm{mg} / \mathrm{ml}$ aprotinin, $750 \mathrm{mg} / \mathrm{ml}$ benzamidine and $1 \mathrm{mM}$ phenylmethylsulfonyl fluoride in PBS pH 7.1. After sonication at $130 \mathrm{~W}$ and $20 \mathrm{kHz}$ for $20 \mathrm{~min}$, the cytosolic fraction (supernatant) and the membrane fraction (precipitate) were separated by centrifugation at $11.000 \mathrm{xg}$ for $10 \mathrm{~min}$. The precipitated pellet was washed then suspended in lysis buffer $0.5 \mathrm{mg} / \mathrm{ml}$ herbimycin A, $0.1 \mathrm{mM}$ sodium vanadate, $25 \mathrm{mg} /$ $\mathrm{ml}$ leupeptin, $50 \mathrm{mg} / \mathrm{ml}$ aprotinin, $750 \mathrm{mg} / \mathrm{ml}$ benzamidine, 1 mM phenylmethylsulfonyl fluoride, $1 \%$ Triton X-100 and $1 \%$ CHAPS in PBS pH 7.1). The membrane fraction was obtained by centrifugation at $13.000 \mathrm{xg}$ for $15 \mathrm{~min}$.

cLf, bLf, cLf-OA, and bLf-OA were biotinylated using N-hydroxysuccinimidebiotin (Sigma Chemicals Co., St. Louis, Mo.) according to the protocol described by the manufacturer.

ELISA micro titer plate (Costar, Cambridge, USA) was coated with carbonate/bicarbonate $\mathrm{pH} 9.6$ buffer as a blank or $50 \mu \mathrm{l}$ of biotinylated cLf/bLf at a concentration of $2 \mathrm{mg} / \mathrm{ml}$ as positive control and $50 \mu \mathrm{l}$ of bacterial membrane fractions preparations at a concentration of $100 \mu \mathrm{g} / \mathrm{ml}$ in carbonate/bicarbonate $\mathrm{pH} 9.6$ buffer for $24 \mathrm{~h}$ at $4^{\circ} \mathrm{C}$. After washing 5 times with PBS at $\mathrm{pH} 7.2$, the plate was blocked by adding $100 \mu \mathrm{l}$ of blocking buffer $(2 \%$ $\mathrm{w} / \mathrm{v}$ gelatin in PBS) for $1 \mathrm{~h}$ at $37^{\circ} \mathrm{C}$. Then the plate was washed 5 times with PBS and $50 \mu \mathrm{l}$ of biotin-labeled cLf, bLf, cLf-OA, or bLf-OA at a concentration of $2 \mathrm{mg} / \mathrm{ml}$ were added to blank and test organisms wells. After $2 \mathrm{~h}$ of incubation at $37^{\circ} \mathrm{C}$, the plate was washed 5 times with PBS, and $50 \mu \mathrm{l}$ of alkaline phosphatase- conjugated streptavidin (BIO-RAD, Alfred Nobel, Hercules, USA) diluted 1:1000 was added, followed by an incubation of $1 \mathrm{~h}$ at $37^{\circ} \mathrm{C}$. After washing five times, p-Nitrophenyl phosphate (p-NPP) was added for color development and optical density was calculated at $405 \mathrm{~nm}$ using an ELISA micro titer plate reader (Micro Plate Reader, BIO-RAD, USA). Results were represented as mean \pm SD of three replicates.

\section{Results and Discussion}

\section{Purification of cLf and bLf}

Both lactoferrins were purified from skimmed milk by onestep affinity chromatography using heparin-Sepharose column and eluted by $0.0-1.0 \mathrm{M} \mathrm{NaCl}$ gradient. Purified fractions were analyzed by SDS-PAGE and then by ELISA (data not shown).

Single discrete band was obtained on $12 \%$ SDS polyacrylamide gel of the two proteins and estimated to be $80 \mathrm{kDa}$ as shown in Figure 1.

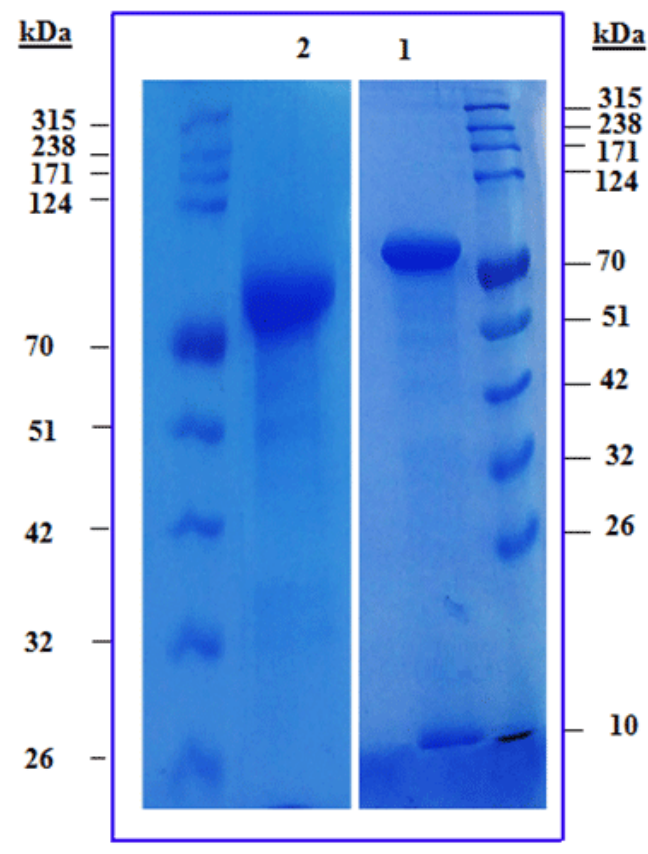

Figure 1: $12 \%$ SDS-PAGE of purified cLf and bLf. Lane 1 represents purified cLf and lane 2 represents purified bLf.

\section{cLf and bLf Activity Determination}

In the present work, cLf and bLf activity was measured by their ability to inhibit superoxide radical generation. Their mean activity was $6.43 \pm 1.71 \mathrm{U} / \mathrm{mg}$ of protein for bLf and $9.84 \pm 1.18 \mathrm{U} /$ mg of protein for cLf.

\section{Oleic Acid Evaluation in the Prepared Complexes}

Concentration values of OA in cLf-OA and bLf-OA complexes were presented as mean $\pm \mathrm{SEM}$; the mean concentration value for cLf-OA was $0.241 \pm 0.02 \mathrm{mM}$ and for bLf-OA was $0.224 \pm 0.025 \mathrm{mM}$. 


\section{Agar Disc Diffusion Assay}

cLf and bLf possessed antibacterial besides antifungal activities against a total of 13 test microorganisms ( 10 bacteria, 1 yeast, and 2 fungi; Tables 1, 2, and 3) and produced concentration dependent inhibition zones Figure 2. The mean diameter of inhibition zone of cLf, evaluated against the test organisms ranged between $7.3 \mathrm{~mm}$ against A. flavus at a concentration of 0.5 $\mathrm{mg} / \mathrm{ml}$ and $39.7 \mathrm{~mm}$ against $P$. aeruginosa at a concentration of 1 $\mathrm{mg} / \mathrm{ml}$. On the other hand, the mean diameter of inhibition zone of bLf, evaluated against the test organisms ranged between 10.0 $\mathrm{mm}$ against $A$. niger at a concentration of $1 \mathrm{mg} / \mathrm{ml}$ and $42.0 \mathrm{~mm}$ against $P$. aeruginosa at a concentration of $1 \mathrm{mg} / \mathrm{ml}$.

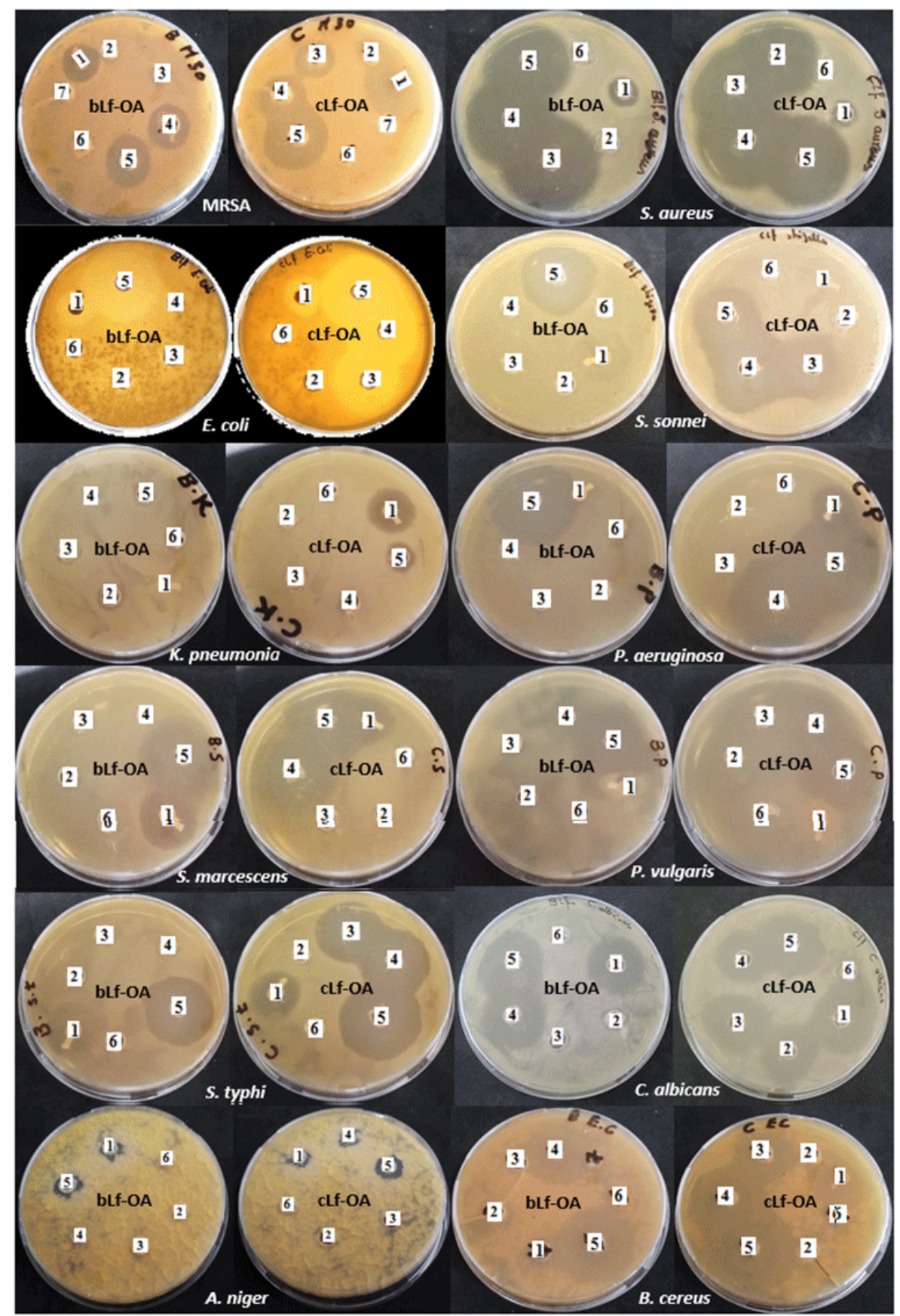

Figure 2: Differential antimicrobial effectiveness of cLf-OA and bLf-OA complexes against several pathogens. 1: represents different antibacterial or antifungal standards; 2: represents cLf/bLf-OA at concentration of $0.0625 \mathrm{mg} / \mathrm{ml}$ in case of Gram-positive bacteria and $0.125 \mathrm{mg} / \mathrm{ml}$ in case of Gram-negative bacteria and fungi; 3: represents cLf $/ \mathrm{bLf}-\mathrm{OA}$ at concentration of $0.125 \mathrm{mg} / \mathrm{ml}$ in case of Gram-positive bacteria and $0.25 \mathrm{mg} / \mathrm{ml}$ in case of Gram-negative bacteria and fungi; 4: represents cLf/bLf-OA at concentration of $0.25 \mathrm{mg} / \mathrm{ml}$ in case of Gram-positive bacteria and $0.5 \mathrm{mg} / \mathrm{ml}$ in case of Gram-negative bacteria and fungi; 5: represents cLf/bLf-OA at concentration of $0.5 \mathrm{mg} / \mathrm{ml}$ in case of Gram-positive bacteria and $1 \mathrm{mg} / \mathrm{ml}$ in case of Gram-negative bacteria and fungi; 6: represents sterile water used as negative control. 
It was observed that neither cLf nor bLf showed any inhibition zones at concentration of $0.125 \mathrm{mg} / \mathrm{ml}$ against any of tested bacterial and fungal pathogens except against $S$. aureus in case of cLf which gave an inhibition zone of $19.3 \mathrm{~mm}$ mean diameter.

Table 1 showed that growth of MRSA, S. aureus, and $B$. cereus was inhibited by cLf at concentrations of $0.25-1 \mathrm{mg} / \mathrm{ml}$, bLf at concentrations of $0.5-1 \mathrm{mg} / \mathrm{ml}$ (except for $S$. aureus that was inhibited by bLf at $0.25-1 \mathrm{mg} / \mathrm{ml}$ ), cLf-OA at $0.0625-0.5$ $\mathrm{mg} / \mathrm{ml}$, and bLf-OA at $0.25-0.5 \mathrm{mg} / \mathrm{ml}$ (except for S. aureus that was inhibited by bLf-OA at $0.125-0.5 \mathrm{mg} / \mathrm{ml}$ ). This indicates a noticeable increase (this increase was mostly higher in case of cLf) in antibacterial activity against test Gram-positive bacteria of both cLf and bLf by binding to OA in the complexes prepared; a suggestion correlates with the previously published studies, which confirmed that oleic acid was active against many Grampositive bacteria thus synergy was evident between cLf/bLf and OA $[20,21]$. OA exhibited antibacterial activity against the Gram-positive bacteria MRSA, S. aureus, and B. cereus (zones of inhibition ranging from 10.0-15.7 mm were observed after overnight incubation Table 1).
As presented in Table 2, growth of E. coli, S. sonnei, and $S$. typhi was inhibited by cLf and cLf-OA at concentrations of 0.25 $1 \mathrm{mg} / \mathrm{ml}$, in addition to bLf and bLf-OA at concentration of 1 $\mathrm{mg} / \mathrm{ml}$. Klebsiella pneumonia was sensitive to cLf and CLf-OA at concentration of $1 \mathrm{mg} / \mathrm{ml}$ but was not sensitive to bLf at $0.25-1$ $\mathrm{mg} / \mathrm{ml}$ or bLf-OA at $0.125-1 \mathrm{mg} / \mathrm{ml}$ and only showed sensitivity towards $2 \mathrm{mg} / \mathrm{ml}$ bLf (12.0 $\mathrm{mm}$ zone of inhibition) and $2 \mathrm{mg} /$ $\mathrm{ml}$ bLf-OA complex (15.3 mm zone of inhibition). cLf/cLf-OA and bLf/bLf-OA inhibited growth of $P$. aeruginosa, P. vulgaris, and $S$. marcescens at concentrations of $0.5-1 \mathrm{mg} / \mathrm{ml}$ and $1 \mathrm{mg} /$ $\mathrm{ml}$, respectively. The inhibitory activity of $\mathrm{OA}$ was lower against Gram-negative E. coli and K. pneumoniae compared to test Grampositive bacteria (zones of inhibition of $3.7 \mathrm{~mm}$ and $3.3 \mathrm{~mm}$, respectively were observed after overnight incubation) while it has no effect on growth of other test Gram-negative bacteria Table 2 . Thus, no change occurred in antibacterial activity against test Gram-negative bacteria of both cLf and bLf by binding to OA in the complexes prepared. This agrees with results obtained by Dilika et al. who reported that OA was inactive against the Gramnegative species they tested [20].

Table 1: Antibacterial activity of cLf-OA and bLf-OA complexes against tested Gram-positive bacteria

\begin{tabular}{|c|c|c|c|c|c|c|c|c|c|c|c|c|c|c|c|c|c|c|}
\hline \multicolumn{19}{|c|}{ Mean diameter of inhibition zone $( \pm 1 \mathrm{~mm})$} \\
\hline \multirow{2}{*}{ Strains } & \multicolumn{3}{|c|}{$\operatorname{cLf}(\mathrm{mg} / \mathrm{ml})$} & \multicolumn{3}{|c|}{ bLf (mg/ml) } & \multirow{2}{*}{$\mathbf{O A}$} & \multicolumn{4}{|c|}{ cLf-OA (mg/ml) } & \multicolumn{4}{|c|}{ bLf-OA (mg/ml) } & \multirow[b]{2}{*}{ CB } & \multirow[b]{2}{*}{ FC } & \multirow[b]{2}{*}{ VA } \\
\hline & 0.25 & 0.5 & 1 & 0.25 & 0.5 & 1 & & 0.0625 & 0.125 & 0.25 & 0.5 & 0.0625 & 0.125 & 0.25 & 0.5 & & & \\
\hline MRSA & 19.3 & 21 & 30.7 & $\mathrm{R}$ & 16.0 & 19.7 & 10.0 & 6.3 & 18.0 & 22.0 & 31.0 & $\mathrm{R}$ & $\mathrm{R}$ & 18.3 & 22.7 & $\mathrm{R}$ & 26.0 & 16.0 \\
\hline S. aureus & 27.3 & 30.7 & 36 & 20.3 & 27.0 & 34.3 & 15.7 & 37.3 & 39.0 & 40.7 & 42.3 & $\mathrm{R}$ & 35 & 35.7 & 37.0 & 12.7 & NT & NT \\
\hline B. cereus & 20 & 23.7 & 32.7 & $\mathrm{R}$ & 19.0 & 20.3 & 11.7 & 7.0 & 19.3 & 24.0 & 32.3 & $\mathrm{R}$ & $\mathrm{R}$ & 19.0 & 24.7 & 11.3 & NT & NT \\
\hline
\end{tabular}

a - Mean of three assays; OA - oleic acid at concentration of $10 \mathrm{mM}$; CB - Carbenicillin; FC - Fucidic acid; VA - Vancomycin antibacterial standard discs at concentrations of 10,10 , and $30 \mu \mathrm{g} / \mathrm{ml}$, respectively; R - Resistant (no inhibition zone); NT - Not tested.

Table 2: Antibacterial activity of cLf-OA and bLf-OA complexes against tested Gram-negative bacteria

\begin{tabular}{|c|c|c|c|c|c|c|c|c|c|c|c|c|c|c|c|c|}
\hline \multicolumn{17}{|c|}{ Mean diameter of inhibition zone ${ }^{a}( \pm 1 \mathrm{~mm})$} \\
\hline \multirow{2}{*}{ Strains } & \multicolumn{3}{|c|}{ cLf (mg/ml) } & \multicolumn{3}{|c|}{ bLf (mg/ml) } & \multirow{2}{*}{$\mathbf{O A}$} & \multicolumn{4}{|c|}{ cLf-OA (mg/ml) } & \multicolumn{4}{|c|}{ bLf-OA (mg/ml) } & \multirow{2}{*}{ GM } \\
\hline & 0.25 & 0.5 & 1 & 0.25 & 0.5 & 1 & & 0.125 & 0.25 & 0.5 & 1 & 0.125 & 0.25 & 0.5 & 1 & \\
\hline E. coli & 22.3 & 26.3 & 35.7 & $\mathrm{R}$ & $\mathrm{R}$ & 31.0 & 3.7 & $\mathrm{R}$ & 26.7 & 28.3 & 36.0 & $\mathrm{R}$ & $\mathrm{R}$ & $\mathrm{R}$ & 37.0 & 18.3 \\
\hline S. sonnei & 21.7 & 29.3 & 31.0 & $\mathrm{R}$ & $\mathrm{R}$ & 35.3 & $\mathrm{R}$ & $\mathrm{R}$ & 22.3 & 31.0 & 32.7 & $\mathrm{R}$ & $\mathrm{R}$ & $\mathrm{R}$ & 36.3 & 23.7 \\
\hline S. typhi & 31.0 & 31.3 & 32.7 & $\mathrm{R}$ & $\mathrm{R}$ & 30.7 & $\mathrm{R}$ & $\mathrm{R}$ & 31.7 & 32.7 & 33.7 & $\mathrm{R}$ & $\mathrm{R}$ & $\mathrm{R}$ & 31.3 & 22.0 \\
\hline K. pneumonia & $\mathrm{R}$ & $\mathrm{R}$ & 12.7 & $\mathrm{R}$ & $\mathrm{R}$ & $\mathrm{R}$ & 3.3 & $\mathrm{R}$ & $\mathrm{R}$ & $\mathrm{R}$ & 14.3 & $\mathrm{R}$ & $\mathrm{R}$ & $\mathrm{R}$ & $\mathrm{R}$ & 21.3 \\
\hline P. aeruginosab & $\mathrm{R}$ & 36.3 & 39.7 & $\mathrm{R}$ & $\mathrm{R}$ & 42.0 & $\mathrm{R}$ & $\mathrm{R}$ & $\mathrm{R}$ & 37.0 & 40.3 & $\mathrm{R}$ & $\mathrm{R}$ & $\mathrm{R}$ & 42.7 & $\mathrm{R}$ \\
\hline S. marcescens & $\mathrm{R}$ & 35.7 & 37.3 & $\mathrm{R}$ & $\mathrm{R}$ & 34.7 & $\mathrm{R}$ & $\mathrm{R}$ & $\mathrm{R}$ & 36.3 & 38.7 & $\mathrm{R}$ & $\mathrm{R}$ & $\mathrm{R}$ & 36.3 & 23.0 \\
\hline P. vulgarisb & $\mathrm{R}$ & 22.7 & 25.0 & $\mathrm{R}$ & $\mathrm{R}$ & 30.7 & $\mathrm{R}$ & $\mathrm{R}$ & $\mathrm{R}$ & 23.0 & 26.7 & $\mathrm{R}$ & $\mathrm{R}$ & $\mathrm{R}$ & 31.3 & $\mathrm{R}$ \\
\hline
\end{tabular}

a - Mean of three assays; OA - oleic acid at concentration of $10 \mathrm{mM}$; GM-Gentamicin antibacterial standard disc at concentration of $10 \mu \mathrm{g} / \mathrm{ml}$; -Resistant (no inhibition zone); b-P. aeruginosa and $P$. vulgaris were not sensitive to GM but were sensitive to chloramphenicol disc ( $30 \mu \mathrm{g}$ ) and showed inhibition zones of $19.0 \mathrm{~mm}$ and $8.3 \mathrm{~mm}$ mean diameter, respectively. 
Table 3 showed that cLf/cLf-OA and bLf/bLf-OA inhibited growth of $A$. niger and A. flavus at $0.5-1 \mathrm{mg} / \mathrm{ml}$ and $1 \mathrm{mg} / \mathrm{ml}$, respectively. Sensitivity of $C$. albicans to cLf, cLf-OA, bLf, and bLfOA was observed at concentrations of $0.5-1,0.125-1,1$, and $0.5-1$ $\mathrm{mg} / \mathrm{ml}$, respectively. Additionally, oleic acid was inhibitory to $C$. albicans after $18 \mathrm{~h}$ of incubation and to a lesser extent against $\mathrm{A}$. niger and A. flavus Table 3; causing a noticeable elevation (this elevation was higher in case of cLf) in antifungal activity against C. albicans of both cLf and bLf by binding to OA in the complexes prepared. These synergy results are in agreement with those of Kabara et al., who found OA to be inhibitory to C. albicans[22].

Overall results revealed that inhibitory activity of cLf and cLf$\mathrm{OA}$ against test microorganisms noticeably exceeded that of bLf and bLf-OA as previously confirmed $[2,3]$.

Table 3: Antifungal activity of cLf-OA and bLf-OA complexes

\begin{tabular}{|c|c|c|c|c|c|c|c|c|c|c|c|c|c|c|c|c|}
\hline \multicolumn{17}{|c|}{ Mean diameter of inhibition zone ${ }^{\mathrm{a}}( \pm 1 \mathrm{~mm})$} \\
\hline \multirow{2}{*}{ Strains } & \multicolumn{3}{|c|}{$\operatorname{cLf}(\mathrm{mg} / \mathrm{ml})$} & \multicolumn{3}{|c|}{ bLf (mg/ml) } & \multirow{2}{*}{$\mathbf{O A}$} & \multicolumn{4}{|c|}{ cLf-OA (mg/ml) } & \multicolumn{4}{|c|}{ bLf-OA (mg/ml) } & \multirow{2}{*}{ AMP } \\
\hline & 0.25 & 0.5 & 1 & 0.25 & 0.5 & 1 & & 0.125 & 0.25 & 0.5 & 1 & 0.125 & 0.25 & 0.5 & 1 & \\
\hline C. albicans & $\mathrm{R}$ & 20.7 & 29.3 & $\mathrm{R}$ & $\mathrm{R}$ & 28.0 & 12.3 & 24.7 & 27.7 & 29.0 & 31.0 & $\mathrm{R}$ & $\mathrm{R}$ & 29.3 & 30.7 & 29.3 \\
\hline A. nigerb & $\mathrm{R}$ & 8.7 & 10.7 & $\mathrm{R}$ & $\mathrm{R}$ & 10.0 & 3.3 & $\mathrm{R}$ & $\mathrm{R}$ & 11.3 & 13.7 & $\mathrm{R}$ & $\mathrm{R}$ & $\mathrm{R}$ & 13.3 & $\mathrm{R}$ \\
\hline A. flavusb & $\mathrm{R}$ & 7.3 & 8.3 & $\mathrm{R}$ & $\mathrm{R}$ & 10.7 & 3.7 & $\mathrm{R}$ & $\mathrm{R}$ & 9.3 & 10.0 & $\mathrm{R}$ & $\mathrm{R}$ & $\mathrm{R}$ & 11.0 & $\mathrm{R}$ \\
\hline
\end{tabular}

a - Mean of three assays; OA - oleic acid at concentration of $10 \mathrm{mM}$; AMP - Amphotericin-B antifungal standard at concentration of $100 \mu \mathrm{g} / \mathrm{ml}$; $\mathrm{R}$ Resistant (no inhibition zone); $\mathrm{b}$ - A. niger and A. flavus were not sensitive to amphotericin-B but were sensitive to nystatin at concentration of 100 $\mu \mathrm{g} / \mathrm{ml}$ and showed inhibition zones of $9.0 \mathrm{~mm}$ and $8.0 \mathrm{~mm}$ mean diameter, respectively.

\section{The MIC Values of Antimicrobial Agents}

cLf showed MIC values of 0.25, 0.125, 0.25, 1, 0.5, 0.5, 0.5, 0.5, 0.5 , and $0.5 \mathrm{mg} / \mathrm{ml}$ for MRSA, S. aureus, B. cereus, K. pneumonia, P. aeruginosa, S. marcescens, P. vulgaris, C. albicans, A. niger, and A. flavus, respectively, while $0.25 \mathrm{mg} / \mathrm{ml}$ for E. coli, S. sonnei, and S. typhi, indicating that it achieved twice and 4 times, respectively higher inhibitory activity than that of bLf against these pathogens Table 4. These data provided further support to the notion that cLf exerted higher antimicrobial activity than bLf.

In view of the MIC results, synergy between cLf or bLf and OA in the prepared complexes was observed against MRSA, S. aureus, B. cereus, and C. albicans causing a 4, 2, 4, and 4 times, respectively increase in cLf antimicrobial activity and a 2 times increase in bLf antimicrobial activity against all of these pathogens. Whereas, the combinations of cLf or bLf and OA in the complexes displayed no synergistic effect against E. coli, K. pneumoniae, A. niger and A. flavus.

Interestingly, $\mathrm{OA}$ concentrations in the prepared complexes were significantly $(\mathrm{P}<0.05)$ lower than its MICs against sensitive test pathogens, thus the higher antimicrobial activity of cLf/bLfOA than free forms was not due to a higher OA concentration in the prepared complexes but confirmed the differential participation of lactoferrin proteins in this elevated complex antimicrobial activity.

Table 4: MIC values of cLf-OA and bLf-OA complexes against various pathogens

\begin{tabular}{|c|c|c|c|c|c|}
\hline \multirow[b]{2}{*}{ Test organism } & \multicolumn{5}{|c|}{ MIC values } \\
\hline & cLf (mg/ml) & bLf (mg/ml) & $\mathrm{OA}(\mathrm{mM})$ & cLf-OA(mg/ml) & bLf-OA(mg/ml) \\
\hline MRSA & 0.25 & 0.5 & 2.5 & 0.0625 & 0.25 \\
\hline S. aureus & 0.125 & 0.25 & 2.5 & 0.0625 & 0.125 \\
\hline B. cereus & 0.25 & 0.5 & 2.5 & 0.0625 & 0.25 \\
\hline E. coli & 0.25 & 1 & 5 & 0.25 & 1 \\
\hline S. sonnei & 0.25 & 1 & $\mathrm{R}$ & 0.25 & 1 \\
\hline S. typhi & 0.25 & 1 & $\mathrm{R}$ & 0.25 & 1 \\
\hline K. pneumonia & 1 & 2 & 5 & 1 & 2 \\
\hline P. aeruginosa & 0.5 & 1 & $\mathrm{R}$ & 0.5 & 1 \\
\hline S. marcescens & 0.5 & 1 & $\mathrm{R}$ & 0.5 & 1 \\
\hline P. vulgaris & 0.5 & 1 & $\mathrm{R}$ & 0.5 & 1 \\
\hline C. albicans & 0.5 & 1 & 2.5 & 0.125 & 0.5 \\
\hline A. niger & 0.5 & 1 & 5 & 0.5 & 1 \\
\hline A. flavus & 0.5 & 1 & 5 & 0.5 & 1 \\
\hline
\end{tabular}




\section{Detection of Lf and its Complexes Binding to Bacterial Membrane Proteins by ELISA}

Biotinylated cLf, bLf, cLf-OA, or bLf-OA reacted significantly $(\mathrm{P}<0.05)$ with bacterial membrane fractions preparations of all test Gram-positive and Gram-negative bacteria compared to blank; carbonate/bicarbonate pH 9.6 buffer Table 5. Wells of ELISA microtiter plate coated with biotinylated cLf or bLf as positive control gave mean \pm SD of $0.829 \pm 0.012$ and $0.75 \pm 0.03$, respectively.

We previously confirmed that biotinylated cLf was recognized by two membrane proteins of MRSA [3]. Additionally, bacterial outer membrane protein $\mathrm{OmpC}$ of $E$. coli and S. typhi was found to complex with the antibacterial eukaryotic protein camel lactoferrin [23].
Our data agree with various studies in the support of the concept that the ferrochelating properties of both lactoferrins are not the only causing factor of their antibacterial activity $[3,23,24-27]$. In fact, the antimicrobial efficiencies of cLf and bLf samples used in this work were not directly correlated with the levels of their partial iron saturation. Here, the less efficient in antimicrobial activity; bLf had higher partial iron saturation $(10 \%)$ than the more potent cLf which was 35\% ironsaturated. This suggests that some antimicrobial mechanisms for lactoferrins not related to ferrochelation are present such as their binding to bacterial membrane proteins. Also, this proves the fact that $\mathrm{OA}$ binding has no effect on Lf binding to bacterial membrane proteins. Even a membrane protein; FadL porin that has highest specific fatty acid binding affinity for oleic acid was characterized in E. coli [28].

Table 5: Detection of Lf and its complexes binding to bacterial membrane proteins by ELISA

\begin{tabular}{|c|c|c|c|c|}
\hline \multirow[b]{2}{*}{ Test sample/ organism } & \multicolumn{4}{|c|}{ OD at $405 \mathrm{~nm}($ mean \pm SD) } \\
\hline & cLf a & bLf a & cLf-OAa & bLf-OAa \\
\hline Blank & $0.058 \pm 0.007$ & $0.04 \pm 0.011$ & $0.042 \pm 0.005$ & $0.056 \pm 0.01$ \\
\hline MRSA & $0.314 \pm 0.012$ & $0.265 \pm 0.02$ & $0.291 \pm 0.007$ & $0.249 \pm 0.041$ \\
\hline S. aureus & $0.261 \pm 0.02$ & $0.35 \pm 0.17$ & $0.337 \pm 0.018$ & $0.217 \pm 0.011$ \\
\hline E. coli & $0.376 \pm 0.07$ & $0.314 \pm 0.03$ & $0.487 \pm 0.016$ & $0.454 \pm 0.026$ \\
\hline S. sonnei & $0.341 \pm 0.12$ & $0.217 \pm 0.012$ & $0.397 \pm 0.008$ & $0.31 \pm 0.007$ \\
\hline S. typhi & $0.322 \pm 0.05$ & $0.346 \pm 0.03$ & $0.338 \pm 0.025$ & $0.347 \pm 0.018$ \\
\hline K.pneumonia & $0.35 \pm 0.073$ & $0.276 \pm 0.014$ & $0.292 \pm 0.023$ & $0.299 \pm 0.012$ \\
\hline P. aeruginosa & $0.311 \pm 0.12$ & $0.327 \pm 0.01$ & $0.275 \pm 0.006$ & $0.306 \pm 0.008$ \\
\hline P. vulgaris & $0.291 \pm 0.12$ & $0.254 \pm 0.07$ & $0.344 \pm 0.014$ & $0.188 \pm 0.01$ \\
\hline
\end{tabular}

aBiotinylated cLf, bLf, cLf-OA, or bLf-OA reacted significantly $(P<0.05)$ with bacterial membrane fractions preparations compared to carbonate/ bicarbonate $\mathrm{pH} 9.6$ buffer used as a blank.

The observed differences in biological activities between cLf and other species of Lf are likely due to the variance in some of its structure-related characteristics. cLf was found to comprise 689 amino acids and contain 17 disulfide bridges and 4 predicted glycosylation sites, one of them in the N-lobe and three found in the C-lobe. The pattern of disulfide bonds in cLf is the same as that found in hLf, but the positions of predicted glycosylation sites are totally different in cLf. Besides, the amino acid sequence of cLf is $70 \%$ identical to the sequences of other lactoferrins, but the first 50 residues or so of cLf N-termini show an identity of less than $40 \%$. Some residues associated with movement of domains in the protein are different in cLf from those found in other lactoferrins, revealing the likelihood of specific structural differences $[29,30]$. We also previously proved that elevated levels of intrinsic disorder in the N-terminal region of cLf can influence the functionality of this region [3].

All the tested microorganisms in this study are of significance as human pathogens, mostly showing resistance to many antibiotics, and chosen to be both Gram-negative and Grampositive bacteria as well as fungi to indicate broad spectrum activity of the formulated cLf/bLf-OA complexes. S. aureus can cause infection in tissues and sites with lowered host resistance as in case of damaged skin or mucous membranes. It is a very common cause of infection in hospitals, mostly capable of infecting newborn babies and surgical patients. Strains of $S$. aureus differ in their degree of susceptibility to particular antibiotics [31]. Moreover, methicillin-resistant strains; MRSA have emerged which complicate the treatment of staphylococci infections because methicillin is considered as the first option in treatment of $S$. aureus infection and also because resistance to methicillin means resistance to all $\beta$-lactam antibiotics. The epidemic of MRSA infections occurs mostly in hospitals. MRSA has become one of the leading causes of death in hospitalized patients around the world [32].

B. cereus causes a minority of food borne illnesses (2-5\%), resulting in severe nausea, diarrhea, and vomiting. Bacillus food borne infections arise because of survival of the bacterial endospores when food is improperly cooked. It produces betalactamases, thus it is resistant to beta-lactam antibiotics [33]. 
E. coli is a pathogen associated with acute gastroenteritis in infants up to 2 years old and rarely in adults with lowered resistance besides infections of urinary tract. Outbreaks of gastroenteritis can cause high fatality rates in maternity nurseries and institutions caring for young children. Antibiotics have insignificant role in treatment of acute stage in severe cases of gastroenteritis as they are not fast enough to stop further body fluid loss [34]. Shigella sonnei causes shigellosis (bacillary dysentery) and produces Shiga toxins that target the vascular endothelium, inhibiting protein synthesis within target cells by a mechanism similar to that of ricin [35]. On the other hand, $S$. typhi spreads by food or water contaminated with feces resulting in typhoid fever, with a risk of death of about $20 \%$ without treatment [36]. While antibiotics are capable of shortening the span of a diarrheal infection, particularly if administered early, pathogenic Shigella and Salmonella species are often resisting the effects of common antibiotics, including ampicillin, trimethoprimsulfamethoxazole, and third generation cephalosporins.

K. pneumonia is a rare cause of bacterial pneumonia but its significance lies in high case mortality in such cases. It is resistant to multiple antibiotics and can produce extendedspectrum beta-lactamases against all beta-lactam antibiotics, except carbapenems [37]. P. aeruginosa is a multidrug resistant pathogen associated with serious diseases-hospital-acquired infections such as ventilator-associated pneumonia and sepsis syndromes [38]. S. marcescens causes an opportunistic infection in respiratory tract, urinary tract, the eye (keratitis, conjunctivitis, endophthalmitis, and tear duct infections), and wounds. Most $S$. marcescens strains are resistant to numerous antibiotics because of the presence of R-factors; intrinsically resistant to macrolides, ampicillin, and first-generation cephalosporins (such as cephalexin) [39]. P. vulgaris is found in individuals in longterm care facilities and hospitals and those with compromised immune systems [40].

Candida infects immunocompromised patients diagnosed with serious diseases such as HIV and cancer. Candida commonly causes nosocomial infections. It affects high risk patients who recently undergone surgery, a transplant or are in the Intensive Care Units, leading to malnutrition and interference with the absorption of medication. A. niger causes fungal ear infections while $A$. flavus is a common cause of fungal sinusitis and cutaneous infections and noninvasive fungal pneumonia.

\section{Conclusion}

This study revealed that cLf and bLf could bind OA and exhibited a much stronger antimicrobial activity than their free forms, especially in case of cLf. Additionally, inhibitory activity of cLf and cLf-OA against test microorganisms noticeably exceeded that of corresponding bLf and bLf-OA. Our study undoubtedly confirmed the presence of no effect by OA binding to lactoferrins on Lf binding to bacterial membrane proteins.

\section{Competing Interests}

The author declares having no competing interests.

\section{References}

1. Sánchez L, Calvo M, Brock JH. Biological role of lactoferrin. Arch Dis Child. 1992;67(5):657-661.

2. Conesa C, Sanchez L, Rota C, Perez MD, Calvo M, Farnaud S, Evans RW. Isolation of lactoferrin from milk of different species: calorimetric and antimicrobial studies. Comp Biochem Physiol B Biochem Mol Biol. 2008;150(1):131-139.

3. Redwan EM, El-Baky NA, Al-Hejin AM, Baeshen MN, Almehdar HA, Elsaway A, et al. Significant antibacterial activity and synergistic effects of camel lactoferrin with antibiotics against methicillin-resistant Staphylococcus aureus (MRSA). Res Microbiol. 2016;167(6):480-491.

4. Brock JH. The physiology of lactoferrin. Biochem Cell Biol. 2002; $80(1): 1-6$.

5. Naidu AS. Lactoferrin: natural, multifunctional, antimicrobial. Boca Raton: CRC Press. 2000; pp. 1-2.

6. Farrington M, Brenwald N, Haines D, Walpole E. Resistance to desiccation and skin fatty acids in outbreak strains of methicillinresistant Staphylococcus aureus. J Med Microbiol. 1992;36(1):56-60.

7. Hazell SL, Graham DY. Unsaturated fatty acids and viability of Helicobacter (Campylobacter) pylori. J Clin Microbiol. 1990;28(5):1060-1061.

8. Bergsson G, Arnfinnsson J, Steingrimsson O, Thormar H. In vitro killing of Candida albicans by fatty acids and monoglycerides. Antimicrob Agents Chemother. 2001;45(11):3209-3212.

9. Nuijens JH, van Berkel PH, Schanbacher FL. Structure and biological actions of Lactoferrin. J Mammary Gland Biol Neoplasia. 1996;1(3):285-295.

10. Ohashi A, Murata E, Yamamoto K, Majima E, Sano E, Katunuma N, et al. New functions of lactoferrin and $\beta$-casein in mammalian milk as cysteine protease inhibitors. Biochem Biophys Res Commun. 2003;306(1):98-103.

11. Baker EN, Baker HM. A structural framework for understanding the multifunctional character of lactoferrin. Biochimie. 2009;91(1):3-10.

12. Fast J, Mossberg AK, Nilsson H. Compact oleic acid in HAMLET. FEBS Lett. 2005;579(27):6095-6100.

13. Redwan EM, Tabll A. Camel lactoferrin markedly inhibits hepatitis $C$ virus genotype 4 infection of human peripheral blood leukocytes. J Immunoassay Immunochem. 2007;28(3):267-277.

14. Parry RM, Brown EM. Lactoferrin conformation and metal binding properties. Advances in experimental medicine and biology. 1974;48:141-160

15. Lowry OH, Rosebrough NJ, Farr AL, Randall RJ. Protein measurement with the Folin phenol reagent. J Biol Chem. 1951;193(1):265-275.

16. Ye X, Wang H, Liu F, Ng T. Ribonuclease, cell-free translation-inhibitory and superoxide radical scavenging activities of the iron-binding protein lactoferrin from bovine milk. Int J Biochem Cell Biol. 2000;32(2):235241.

17. Duncombe WG. The colorimetric micro-determination of long-chain fatty acids. Biochem J. 1963;88(1):7-10.

18. Wikler MA. Performance Standards for Antimicrobial Susceptibility Testing. Eighteenth Informational Supplement. M100-S18. ed. C.L.S.I. (Clinical and Laboratory Standard Institute), Pennsylvania, PA, USA. 2008 
19. Cockerill FR, Wikler MA, Alder J, Dudley MN, Eliopoulos GM, Ferraro MJ, Hardy DJ, Hecht DW, Hindler JA, Patel JB, Powell M, Swenson JM, Thomson RB, Traczewski MM, Turnidge JD, Weinstein MP, Zimmer BL. Methods for Dilution Antimicrobial Susceptibility Tests for Bacteria That Grow Aerobically; Approved Standard. CLSI document M07-A9.9. 9 ed. C.L.S.I. (Clinical and Laboratory Standard Institute), Pennsylvania, PA, USA. 2012.

20. Dilika F, Bremner PD, Meyer JJ. Antibacterial activity of linoleic and oleic acids isolated from Helichrysum pedunculatum: a plant used during circumcision rites. Fitoterapia. 2000;71(4):450-452.

21. Choi JS, Park NH, Hwang SY, Sohn JH, Kwak I, Cho KK, et al. The antibacterial activity of various saturated and unsaturated fatty acids against several oral pathogens. J Environ Biol. 2013;34(4):673-676.

22. Kabara JJ, Swieczkowski DM, Conley AJ, Truant JP. Fatty acids and derivatives as antimicrobial agents. Antimicrob Agents Chemother. 1972;2(1):23-28.

23. Sundara Baalaji N, Ravi Acharya K, Singh TP, Krishnaswamy S. Highresolution diffraction from crystals of a membrane-protein complex: bacterial outer membrane protein OmpC complexed with the antibacterial eukaryotic protein lactoferrin. Acta Cryst. 2005;F61:773775 .

24. Arnold RR, Cole MF, Mcghee JR. A bactericidal effect for human lactoferrin. Science. 1977;197(4300):263-265.

25. Ellison RT III, Giehl TJ, LaForce FM. Damage of the outer membrane of enteric gram negative bacteria by lactoferrin and transferrin. Infect Immun. 1988;56(11): 2774-2781.

26. Ellison RT III, LaForce FM, Giehl TJ, Boose DS, Dunn BE. Lactoferrin and transferring damage of the Gram negative outer membrane is modulated by Ca2+ and Mg2+. J Gen Microbiol. 1990;136(7):14371446.

27.Visca P, Dalmastri C, Verzili D, Antonini G, Chiancone E, Valenti P. Interaction of lactoferrin with Escherichia coli cells and correlation with antibacterial activity. Med Microbiol Immunol. 1990;179(6):323333.

28. Black PN. Characterization of FadL-SPECIFIC fatty acid binding in Escherichia coli. Biochim Biophys Acta. 1990;1046(1):97-105.
29. Khan JA, Kumar P, Paramasivam M, Yadav RS, Sahani MS, Singh TP, et al. Camel lactoferrin, a transferrin-cum-lactoferrin: crystal structure of camel apolactoferrin at 2.6 A resolution and structural basis of its dual role. J Mol Biol. 2001;309(3):751-761.

30. Redwan EM, El-Fakharany EM, Uversky VN, Linjawi MH. Screening the anti- infectivity potentials of native $\mathrm{N}$ - and $\mathrm{C}$-lobes derived from the camel lactoferrin against hepatitis $\mathrm{C}$ virus. BMC complementary and alternative medicine. 2014;14: 219.

31. Mele T, Madrenas J. TLR2 signalling: at the crossroads of commensalism, invasive infections and toxic shock syndrome by Staphylococcus aureus. Int J Biochem Cell Biol. 2010;42(7):1066-1071.

32. Nguyen GC, Patel H, Chong RY. Increased prevalence of and associated mortality with methicillin-resistant Staphylococcus aureus among hospitalized IBD patients. Am J Gastroenterol. 2010;105:371-377. Doi:10.1038/ajg.2009.581

33. Kotiranta A, Lounatmaa K, Haapasalo M. Epidemiology and pathogenesis of Bacillus cereus infections. Microbes Infect. 2000;2(2):189-198.

34. Todar K. Pathogenic E. coli. Online Textbook of Bacteriology. University of Wisconsin-Madison Department of Bacteriology. 2007

35. Torres AG. Current aspects of Shigella pathogenesis. Rev Latinoam Microbiol. 2004;46(3-4):89-97.

36. WHO/Typhoid fever. www.who.int. Archived from the original on 2017-07-27.

37. Hudson C, Bent Z, Meagher R, Williams K. Resistance Determinants and Mobile Genetic Elements of an NDM-1-Encoding Klebsiella pneumoniae Strain. PLOS ONE. 2014;9(6):e99209.

38. Balcht A, Smith R. Pseudomonas aeruginosa: Infections and Treatment. Infectious Disease and Therapy Series. 1994(9); 615.

39. Pathogen Safety Data Sheets: Infectious Substances - Serratia spp. Public Health Agency of Canada. 30 April 2012.

40.Sydnor E. Hospital Epidemiology and Infection Control in Acute-Care Settings. Clinical Microbiology Reviews. 2011;24(1):141-173. 